University of Nebraska - Lincoln

DigitalCommons@University of Nebraska - Lincoln

\title{
8-2008
}

\section{Measuring Immigration's Effects on Labor Demand: A Reexamination of the Mariel Boatlift}

Örn B. Bodvarsson

St. Cloud State University, USA, obbodvarsson@stcloudstate.edu

Hendrik F. Van den Berg

University of Nebraska-Lincoln, hvan-den-berg1@unl.edu

Joshua J. Lewer

Bradley University, jlewer@bradley.edu

Follow this and additional works at: https://digitalcommons.unl.edu/econfacpub

Part of the Economics Commons

Bodvarsson, Örn B.; Van den Berg, Hendrik F.; and Lewer, Joshua J., "Measuring Immigration's Effects on Labor Demand: A Reexamination of the Mariel Boatlift" (2008). Economics Department Faculty Publications. 44.

https://digitalcommons.unl.edu/econfacpub/44

This Article is brought to you for free and open access by the Economics Department at DigitalCommons@University of Nebraska - Lincoln. It has been accepted for inclusion in Economics Department Faculty Publications by an authorized administrator of DigitalCommons@University of Nebraska - Lincoln. 
Published in Labour Economics 15:4 (August 2008), pp. 560-574; doi 10.1016/j.labeco.2008.04.003 Copyright (C) 2008 Elsevier B.V. Used by permission.

Published online May 2, 2008.

\title{
Measuring immigration's effects on labor demand: A reexamination of the Mariel Boatlift
}

\author{
Örn B. Bodvarsson, ${ }^{a, b}$ Hendrik F. Van den Berg, ${ }^{b, c}$ \\ and Joshua J. Lewer ${ }^{\mathrm{d}}$ \\ a St. Cloud State University, USA \\ b IZA, Germany \\ ${ }^{c}$ University of Nebraska-Lincoln, USA \\ d Bradley University, USA \\ Corresponding author - Ö. B. Bodvarsson, Department of Economics, \\ St. Cloud State University, St. Cloud, MN, 56301, USA; tel 320 308-2225, fax 320 \\ 308-2228, email obbodvarsson@stcloudstate.edu
}

\begin{abstract}
Why do immigration shocks tend to have benign effects on native wages? One reason is that immigrants as consumers contribute to the demand for their services. We model an economy where workers spend their wages on a locally produced good, then test it via a reexamination of the 1980 "Mariel Boatlift" using Wacziarg's Channel Transmission methodology. Current Population Survey data on workers in 9 different retail labor markets and Survey of Buying Power data on retail spending by consumers in Miami and four comparison cities are used. We find strong evidence that the Mariel Boatlift augmented labor demand.
\end{abstract}

Keywords: immigration, consumption, wages, channels, retail

\section{Introduction}

After over twenty-five years of research and a plethora of studies for different countries, it is now well established that immigration has relatively benign effects on native employment outcomes. Card's (1990) well-known study of the Mariel Boatlift provided a stunning example of how even a sudden large inflow of immigrants did not have a detrimental effect

The authors thank Stephen Bronars, Raymond Robertson, participants at the 2007 ESPE and EALE conferences for helpful comments, Opal Dicenso for assistance with preparation of the data set, and the University of Nebraska-Lincoln for funding to purchase some of the data and software used in this study. The authors bear full responsibility for any errors and are pleased to provide the data used in this study upon request. 
on the local labor market. ${ }^{1}$ More generally, Friedberg and Hunt's (1995) survey concluded that a $10 \%$ increase in a locality's immigrant population share depresses native-born wages by usually no more than an average of $1 \%$. More recent surveys by Dustmann and Glitz (2005), Gaston and Nelson (2001), and Card (2005) draw similar conclusions. Longhi et al.'s (2005) meta-analysis found that a 1 percentage point increase in the fraction of immigrants in the labor force, on average, reduces wages by about $0.1 \%$. Even studies using the skill cell approach are mixed. Borjas (2003), for example, estimated that a 10\% increase in a skill cell's immigrant share reduces the wages of competing native workers nationwide by $3-4 \%$, but Friedberg (2001) found that the huge flows of highly educated persons from the former Soviet Union to Israel during the first half of the 1990s had no discernible impacts on native employment outcomes.

Two reasons why researchers find no wage effects of immigration are: (1) immigrant inflows and receiving area economic conditions could be simultaneously determined; and (2) thanks to flexible markets, an immigration shock will activate various adjustment processes that return wages to their pre-migration levels. These adjustment processes could include: (i) capital inflows (cf. Leamer and Levinsohn, 1995); (ii) internal out-migration (cf. Borjas et al., 1997; Filer, 1992; Card, 2001; Borjas, 2006; Federman et al., 2006); and (iii) the adoption of more immigrant-intensive technologies (cf. Poot et al., 1988; Lewis, 2003; Lewis, 2004; Lewis, 2005; Gandal et al., 2004). ${ }^{2}$ The evidence on these adjustment processes is limited and mixed. Freeman (2006) observes that there is not yet a consensus on the importance of internal migration responses to an immigration shock. ${ }^{3}$ In fact, Longhi et al. (2005, pp. 473) conclude that "The challenge for further research is to identify and separate carefully the many adjustment processes that have given rise to [the observation that immigration's effect on receiving area wages is benign]."

There is another adjustment process that is potentially powerful, but which has received surprisingly little attention in the literature: Immigrants increase local labor demand by spending income on local goods and services. That is, Say's Law may apply to immigration because immigrants, as consumers, demand their own labor. A derived demand response to immigration was first suggested in a macroeconomic context by Mishan and Needleman (1966, 1968). Harrison (1983) suggested that the demand-augmenting effects of immigration could help explain why immigration did not exert adverse effects on native-born workers in Australia. Greenwood and Hunt (1984) conjectured that immigration can boost aggregate demand, while Greenwood (1994) argued that output demand is a potential "channel of adjustment" to an immigration shock. Greenwood and Hunt (1995) tested a model in which immigrant consumption influences demand. However, they did not isolate this effect on wages. Altonji and Card (1991) also included immigrant consumption in their model,

\footnotetext{
${ }^{1}$ Other famous natural experiments of exogenous immigration include Hunt's (1992) study of the 1962 repatriation of French colonists from Algeria to France, Carrington and de Lima's (1996) study of the repatriation of overseas Portugese following the independence of Portugal's African colonies in 1973, Friedberg's (2001) study of Jewish migration to Israel after the fall of the Soviet Union and Suen's (2000) study of the large influx of Chinese refugees to Hong Kong. These studies generally find that immigration shocks cause mostly benign effects on native-born workers. A number of recent natural experiments find more mixed results, though. For example, Angrist and Kugler (2003) use a panel data set for EEA countries for 1983-99 to show that ceteris paribus native job losses will be greater in countries with less market flexibility, particularly when inflexibility is due to product market restrictions.

${ }^{2}$ Furthermore, immigrants and natives could also be complements (cf. Grieco and Ray, 2004).

${ }^{3}$ It should be noted that Borjas (2006) provided evidence from U.S. city data that internal migration responses by natives reduce the measured effect of immigration on wages by 40 to $60 \%$. Also, in an unpublished paper, Lewis (2005) provides evidence supporting the hypothesis that in markets with higher relative supply of lessskilled labor, comparable plants use more labor-intensive technologies.
} 
but did not actually test for it. ${ }^{4}$ Other studies indicate that immigration can boost labor demand significantly. Hercowitz and Yashiv (2002) study the 1990s mass migration of Russian Jews to Israel. They find that when immigration boosts consumer demand, any negative effects on native employment are delayed by about a year. Saiz (2003) found strong evidence that immigration boosted rental prices in Miami for the first few years following the Mariel Boatlift. Ottaviano and Peri (2005) and Saiz (2007) found that U.S. immigration boosted housing prices nationwide. These studies do not consider the effects of immigrant consumption on native-born wages, though. In this paper, we revisit Card's Mariel Boatlift study to estimate whether the absence of a negative labor market outcome was the result of the Cuban immigrants generating their own labor demand.

This study most closely resembles Bodvarsson and Van den Berg's (2006) study of Hispanic immigration to the meatpacking industry in Dawson County, Nebraska, which shows that immigration can substantially boost consumer demand. Their study has some limitations, though. First, the labor market in Bodvarsson and Van den Berg's model is uniquely segmented because immigrants work exclusively in an export sector, but consume locally. While this segmentation facilitated their econometrics, it overlooks that immigrants often consume and work in the same sector, e.g. retail goods and services. Second, Bodvarsson and Van den Berg assume perfect substitution. However, human capital endowments of natives and immigrants will likely differ. ${ }^{5}$

\section{A general equilibrium model of wages}

Our model proceeds from the "production function" approach where native and immigrant labor groups are separate inputs. This approach is due originally to Grossman (1982) and has been most recently utilized by Ottaviano and Peri $(2005,2006)$, Bodvarsson and Van den Berg (2006), and Cortes (2006). ${ }^{6}$

Consider a small, perfectly competitive open economy where the representative firm seeks to maximize profit by producing a good using native labor $(\mathrm{N})$ and immigrant labor (I). To keep the analysis simple, we exclude capital from the production function, which is equivalent to keeping the supply of capital perfectly elastic. Production is described by the quadratic function,

$$
Q=\alpha_{1} N-\alpha_{2} N^{2}+\alpha_{3} I-\alpha_{4} I^{2}-\alpha_{5} N I,
$$

where $Q$ is output and $\alpha_{1}$ through $\alpha_{5}$ are positive coefficients. ${ }^{7}$ Note that the minus sign next to $\alpha_{5}$ reflects the assumption that native- and foreign-born workers are competitive (substitute) inputs.

\footnotetext{
${ }^{4}$ Altonji and Card present a model of the local wage and employment effects of immigration in which immigrants consume a fraction of their output. Their model yields the prediction that when immigrants consume a larger proportion of their output, local wages are less sensitive to immigrant inflows.

${ }^{5}$ As Chiswick (1978), LaLonde and Topel (1991), and others have argued, immigrants and natives are imperfect substitutes because of differences in human capital endowments.

${ }^{6}$ Our model bears some similarity to Cortes (2006), who examines the relationship between immigration shocks and the prices of non-tradable goods. She derives the implication that a larger supply of unskilled immigrant labor will depress the market price of unskilled-intensive goods, where the lower price is due to lower immigrant wages. Immigrants consume what they produce in Cortes's model, but a homothetic production function neutralizes any effects of immigration on labor demand. Consequently, Cortes's model is confined to the analysis of product supply effects, not the demand effects which are the subject of this study.

${ }^{7}$ Examples of this production function are found in Frisch (1965, pp. 59) and Doll and Orazem (1984, pp. 12829). Bodvarsson and Partridge (2001) use a similar equation in a study of black/white salary differentials in the National Basketball Association.
} 
We chose the quadratic function above for several reasons. First, a production function consistent with a traditional model of distributional effects greatly facilitates the comparison of our theoretical and empirical results with those of many other studies in this area, including especially the important study of Card (1990). ${ }^{8}$ Second, our test is of the retail industry, in which most workers are low-skilled and substitutes for other lowskilled workers in the same profession. Third, the quadratic function provides easy-tosign closed form solutions for wages. ${ }^{9}$ A closed form expression for the native-born wage makes it much easier to theoretically and empirically measure the effects of immigrant consumption on the wage. While the quadratic function has some restrictions, it is overall the functional form most convenient for the analysis at hand. ${ }^{10}$

Assume an output price $\mathrm{P}$, immigrant wage $W_{I}$ and native wage $W_{N}$. The market supply of immigrant labor, $\theta_{I^{\prime}}$ depends upon the real wage $\left(W_{I} / P\right)$, a real reservation wage, $V_{I}$, and other factors influencing migration (i):

$$
\theta_{I}=\left(\frac{i}{V_{I}}\right)\left(\frac{W_{I}}{P}\right) .
$$

The supply of native labor depends upon the real wage and a real reservation wage $V_{N}$ :

$$
\theta_{N}=\left(\frac{n}{V_{I}}\right)\left(\frac{W_{N}}{P}\right) .
$$

There are $H$ employers. Profit maximization and labor market equilibrium yield the partial equilibrium native worker wage,

$$
W_{N}=\frac{P\left[\left(\frac{H}{\varepsilon\left(\frac{H}{\varepsilon \alpha_{5}}+\frac{i}{V_{I}}\right)}\right)\left(\frac{\alpha_{3}}{\alpha_{5}}-\frac{\alpha_{1}}{2 \alpha_{2}}\right)+\frac{2 \alpha_{1} \alpha_{4}}{\alpha_{5}}-\alpha_{3}\right]}{2 \alpha_{4}\left(\frac{1}{\alpha_{5}}+\left(\frac{n}{V_{N}}\right)\left(\frac{\phi}{H}\right)\right)-\left(\frac{H}{2 \varepsilon \alpha_{2}\left(\frac{H}{\varepsilon \alpha_{5}}+\frac{i}{V_{I}}\right)}\right)}, \text { where } \phi=\frac{2 \alpha_{2}}{\alpha_{5}}-\frac{\alpha_{5}}{2 \alpha_{4}}
$$

If $\alpha_{5}$ is positive and not too high, then $\left(\alpha_{3} / \alpha_{5}\right)>\left(\alpha_{1} / 2 \alpha_{2}\right),\left(2 \alpha_{1} \alpha_{4} / \alpha_{5}\right)>\alpha_{3}$, and the numerator in expression (4) will be positive. The denominator will be positive if $2 \alpha_{4}\left[1 / \alpha_{5}+\right.$ $\left.\left(n / V_{N}\right)(\varphi / H)\right]>H /\left[2 \varepsilon \alpha_{2}\left(H / \varepsilon \alpha_{5}+i / V_{I}\right)\right]$. In the analysis that follows, it is assumed that these restrictions hold.

\footnotetext{
${ }^{8}$ A number of recent studies do find evidence that native- and foreign-born workers can be complements in production (e.g. Ottaviano and Peri, 2005; Ottaviano and Peri, 2006; Kugler and Yuksel, 2006). However, those are cases of cross-cell or cross-industry complementarity. In this study, we examine one industry where native and immigrant human capital endowments tend to be very similar, hence the two groups are much more likely to be substitutes.

${ }^{9}$ An alternative function would be, for example, the nested CES, used by Borjas (2003), Ottaviano and Peri (2005, 2006), Cortes (2006), and others. A distinct advantage of the CES function is that one can easily derive expressions for factor price elasticities, but a disadvantage is that it is often not possible to obtain closed form expressions for wages or employment rates.

${ }^{10}$ The quadratic function has some features that are not general to all production functions, which should be kept in mind when interpreting our model. First, some parameter restrictions are necessary to sign marginal effects. Second, the function can yield negative output when the labor force comprises either a very high fraction of natives or a very high fraction of immigrants. Third, the function is not homogeneous, which can preclude convenient measurement of immigration's distributional effects. None of these restrictions are severe for our analysis, though.
} 
Supply-push immigration will result in a lower equilibrium native wage,

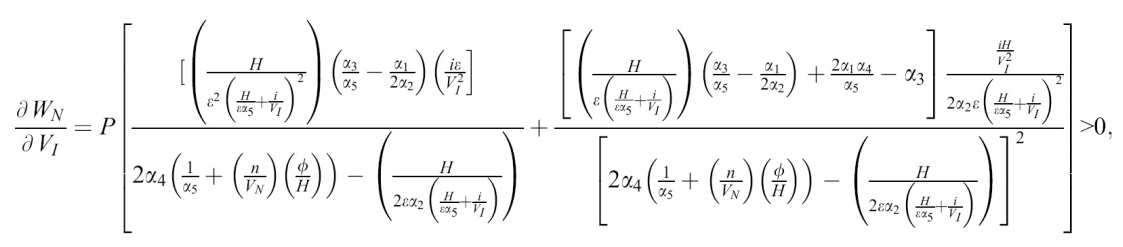

Expression (5) illustrates the "input substitution effect": Greater immigrant labor supply reduces the immigrant wage, leading to substitution of immigrants and a lower native wage.

Output demand $Q_{\mathrm{DR}}$ depends upon aggregate consumer income spent locally $Y$ and price,

$$
Q_{\mathrm{DR}}=\psi_{1} Y-\psi_{2} P
$$

whereas supply $Q_{\mathrm{SR}}$ depends upon price and the two wages,

$$
Q_{\mathrm{SR}}=\delta_{1} P-\delta_{2} W_{N}-\delta_{3} W_{I}
$$

A consumer's income includes wages and distributed profits. Natives spend all their earnings, but immigrants spend only a fraction $(\mathrm{k})$ of their incomes locally. Thus,

$$
Y=W_{N} \theta_{N}+k W_{I} \theta_{I}+\lambda,
$$

where $\lambda$ is distributed profits. When Equation (8) is substituted into Equation (6), product demand clearly depends on immigration:

$$
Q_{\mathrm{DR}}=\psi_{1}\left(W_{N} \theta_{N}+k W_{I} \theta_{I}+\lambda\right)-\psi_{2} P .
$$

Now set Equation (9) equal to Equation (7) and solve for $P$. Equilibrium price $\left(P^{*}\right)$ is:

$$
P^{*}=\frac{W_{N} *\left(\psi_{1} \theta_{N} *+\delta_{2}\right)+W_{I}^{*}\left(k \theta_{I} *+\delta_{3}\right)+\psi_{1} \lambda}{\psi_{2}+\delta_{1}},
$$

where $\theta_{N}{ }^{*}=n W_{N}^{*} / V_{N} P$ and $\theta_{I}^{*}=i W_{I}^{*} / V_{I} P, W_{N}^{*}$ and $W_{I}^{*}$ are partial equilibrium wages, $\theta_{N}^{*}$ is equilibrium native employment, and $\theta_{I}^{*}$ is equilibrium immigrant employment. Substituting these wages into Equation (10), product price in general equilibrium is:

$$
\begin{aligned}
& P^{*}=\frac{\frac{\psi_{1} \lambda}{\psi_{2}+\delta_{1}}}{\left[1-\left(\frac{\left(\frac{\psi_{1} n A^{2}}{V_{N}}\right)+\delta_{2} A+\left(\frac{k i B^{2}}{V_{I}}\right)+\left(\delta_{3} B\right)}{\psi_{2}+\delta_{1}}\right)\right]}, \quad \text { where } A=\frac{\left[\left(\frac{H}{\varepsilon\left(\frac{H}{\varepsilon \alpha_{5}}+\frac{i}{V_{I}}\right)}\right)\left(\frac{\alpha_{3}}{\alpha_{5}}-\frac{\alpha_{1}}{2 \alpha_{2}}\right)+\frac{2 \alpha_{1} \alpha_{4}}{\alpha_{5}}-\alpha_{3}\right]}{2 \alpha_{4}\left(\frac{1}{\alpha_{5}}+\left(\frac{n}{V_{N}}\right)\left(\frac{\phi}{H}\right)\right)-\left(\frac{H}{2 \varepsilon \alpha_{2}\left(\frac{H}{\varepsilon \alpha_{5}}+\frac{i}{V_{I}}\right)}\right)} \text { and }
\end{aligned}
$$

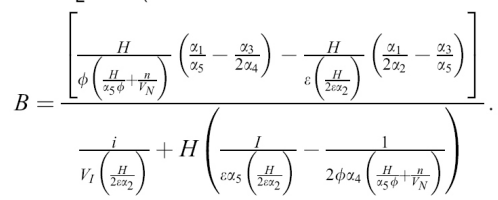

In general equilibrium, how does an immigration shock affect product price? Suppose the shock is triggered by a fall in the source country wage ( $V_{I}$ falls). Differentiating ex- 
pression (11) with respect to the immigrant reservation wage, we obtain

$$
\frac{\partial P^{*}}{\partial V_{I}}=\frac{\left(\frac{\psi_{1} \lambda}{\left(\psi_{2}+\delta_{1}\right)^{2}}\right)\left[\frac{\partial A}{\partial V_{I}} \frac{2 \psi_{1} n A}{V_{N}}+\frac{\partial A}{\partial V_{I}} \delta_{2}+\frac{\partial B}{\partial V_{I}}\left(\frac{2 k B i}{V_{I}}+\delta_{3}\right)-\frac{\partial B}{\partial V_{I}} \frac{k B^{2} i}{V_{I}^{2}}\right]}{\left[1-\left(\frac{\left.\frac{\psi_{1} n A^{2}}{V_{N}}\right)+\left(\delta_{2} A\right)+\left(\frac{k B^{2}}{V_{I}}\right)+\left(\delta_{3} B\right)}{\psi_{2}+\delta_{1}}\right]^{2} \cdot\right.}
$$

According to the bracketed expression in expression (12)'s numerator, an immigration shock induces four effects on price. Starting from the left, the first three effects lower price - out-migration, a drop in each native's income and a drop in each immigrant's income, respectively. The fourth effect contributes to an increase through more consumers. The sum of these effects can be positive, negative or neutral.

The general equilibrium native wage is obtained by substituting Equation (11) into Equation (4):

$$
W_{N}=\frac{\left[\frac{\frac{\psi_{1} \lambda}{\psi_{2}+\delta_{1}}}{1-\left(\frac{\left.\frac{\psi_{1} n A^{2}}{V_{N}}\right)+\left(\delta_{2} A\right)+\left(\frac{k i B^{2}}{V_{I}}\right)+\left(\delta_{3} B\right)}{\psi_{2}+\delta_{1}}\right)}\right]\left[\left(\frac{H}{\varepsilon\left(\frac{H}{\varepsilon \alpha_{5}}+\frac{i}{V_{I}}\right)}\right)\left(\frac{\alpha_{3}}{\alpha_{5}}-\frac{\alpha_{1}}{2 \alpha_{2}}\right)+\frac{2 \alpha_{1} \alpha_{4}}{\alpha_{5}}-\alpha_{3}\right]}{2 \alpha_{4}\left(\frac{1}{\alpha_{5}}+\left(\frac{n}{V_{N}}\right)\left(\frac{\phi}{H}\right)\right)-\left(\frac{H}{2 \varepsilon \alpha_{2}\left(\frac{H}{\varepsilon \alpha_{5}}+\frac{i}{V_{I}}\right)}\right)} .
$$

Differentiating Equation (13) with respect to the immigrant reservation wage, we find that

$$
\frac{\partial W_{N}}{\partial V_{I}}=\frac{\partial P^{*}}{\partial V_{I}} A+P^{*} \frac{\partial A}{\partial V_{I}} .
$$

The ceteris paribus effect of an immigration shock on the native wage is the sum of two effects. First, there is the "consumer demand effect" (the first term on the right hand side of Equation (14)). This is the change in the wage occurring when immigration induces a change in consumer demand. The consumer demand effect can be positive, negative or neutral. Second, there is the input substitution effect. The native wage will rise if the consumer demand effect is sufficiently positive and the input substitution effect is relatively small.

\section{A test of the model}

We chose as our test case the so-called "Mariel Boatlift," perhaps the most famous modern day natural experiment of exogenous international migration. The Mariel Boatlift involved the migration of some 120,000 Cuban refugees on a flotilla of privately chartered boats to Miami from May to September, 1980. Approximately one-half of the Mariel refugees settled permanently in the Miami metropolitan area, resulting in a $7 \%$ increase in Miami's labor force. Many who remained in Miami were absorbed by the retail goods and services, textile and apparel manufacturing, and construction industries. We contend that Miami's retail sector in particular was very likely to have been affected by the immigration shock. Lewis (2004) provides evidence that, of the various Miami-area industries that absorbed the Marielitos, retail industries such as motor vehicle sales, hotels and motels, grocery stores and restaurants experienced substantial increases in Cuban employment during the 1980 s. 
We test for a consumer demand effect on retail wages in Miami following the Mariel immigration shock through the application of an econometric methodology due originally to Tavares and Wacziarg (2001) and Wacziarg (1998, 2001). This methodology allows for the estimation of a simultaneous equations regression model in which an independent variable affects the dependent variable through different channels, to use Wacziarg's exact terminology. The model includes: (1) separate channel equations, each describing the hypothesized process by which the fundamental causal variable influences the dependent variable; and (2) an aggregate equation that explains the dependent variable and includes, among other determinants, each of the channel variables as explanatory variables. The overall effect of the fundamental causal variable, immigration, on the dependent variable, native wages, is the combined effect of immigration on each channel and each channel's effect on the overall wage. Wacziarg's methodology allows us to estimate the complete effect of immigration on the native wage as the sum of the input substitution and consumer demand effects. This methodology has the added advantage of providing the relative contributions of the consumer demand and input substitution effects.

In order to empirically distinguish between the input substitution and consumer demand effects, we test the following two hypotheses: (1) immigration influences the demand for native labor through its effects on the immigrant wage $\left(W_{I}\right)$; and (2) immigration influences the demand for native labor through its effects on retail sales per capita $(P)$. Suppose our study of the variables $W_{I}$ and $P$ also suggests that immigration is not the only explanatory variable, that the vector of variables $R$ also explains some of the variation in $W_{I^{\prime}}$ and that the vector of explanatory variables $S$ helps to explain $P$. Accordingly, we estimate the simultaneous-equations regression model consisting of the following aggregate equation,

$$
W_{N}=a_{0}+a_{1}\left(W_{I}\right)+a_{2}(P)+a_{3}(Z)+u,
$$

and the following two channel equations,

$$
\begin{aligned}
& W_{I}=b_{0}+b_{1}\left(\theta_{I}\right)+b_{2}(R)+u \\
& P=c_{0}+c_{1}\left(\theta_{I}\right)+c_{2}(S)+u
\end{aligned}
$$

If our estimation procedure is consistent and the estimates are statistically significant, we will gain estimates of the relative strengths of the two channels through which immigration is hypothesized to influence wages. The effect of immigration on wages through the $W_{I}$ channel is $\left(b_{1} \cdot a_{1}\right)$ and the effect of immigration through the $P$ channel is $\left(c_{1} \cdot a_{2}\right)$. It follows that the total effect of immigration on the wage is $\left(a_{2} \cdot c_{1}\right)+\left(a_{1} \cdot b_{1}\right)$.

The right-hand side variables included in Equation (15) are the city-specific minimum wage, real U.S. gross domestic product, a time trend to proxy technological progress, and the federal Department of Housing and Urban Development's city-specific fair market rent. The minimum wage and rent variables capture factors unique to the local labor market, such as cost of living, the policy environment, and amenities. U.S. GDP and the technology trend capture the overall national influences on local labor demand. In Equation (16), $\theta_{\mathrm{I}}$ is Cuban immigrant density within each city. Other variables in Equation (16) include city-specific birth and death rates, highest school grade attained and net emigration to each city by other native labor. These are intended to capture various factors that determine the supply of native labor, such as the natural growth of population, net inflows, and the human capital component of labor. Equation (17) includes variables likely to influence overall consumer demand, including the federal funds rate, the national unemployment rate, non-labor income $(\lambda)$, and the growth of real U.S. GDP. Adding $\theta_{I}$, the relative supply of immigrant workers, to the equation then permits us to measure the marginal effect of immigrants on consumer demand, all other things equal. 
Our primary data source consists of observations on 6569 persons who were part of the Merged Outgoing Rotation Group (MORG) samples of the Current Population Survey (CPS) for 1979-85 in Miami (approximately 11\% of the observations) and the same 4 comparison cities used in Card's (1990) study - Atlanta (approximately 12.5\% of the observations), Tampa (11\%), Houston (17\%) and Los Angeles (48.5\%). The CPS observations used in our study are specifically of persons employed in 9 different retail CPS-classified categories:

\section{Grocery stores \\ Eating and drinking places \\ Department, variety and general merchandise stores \\ Apparel and accessories stores \\ Furniture and household furnishings stores \\ Motor vehicle dealers \\ Gasoline service stations \\ Lumber and building material retailing and hardware stores \\ Drug stores}

Following Card's (1990) approach, we break the CPS sample down by four categories for Miami (whites, blacks, Cubans and Hispanics) and three categories for the other cities (whites, blacks and Hispanics). Because of the extremely small number of Cubans residing in the four comparison cities, the CPS includes a separate category for Cubans only for Miami. Of the 722 observations in our sample for Miami, 209 (29\%) self-reported being Cuban. To control for differences in skill levels between retail workers, we use educational attainment (measured by highest grade attended), age at the time of the survey, and potential labor market experience (constructed from the sample as: age - highest grade attended -5) as human capital controls. For our sample, the mean age of respondents is 30 years, mean grade attended is approximately 12 years and mean potential labor market experience is 13 years. The respondents earned on average $\$ 4.70$ per hour and approximately $\$ 160$ per week before taxes and worked an average of approximately 33 hours per week. Because of the nature of the retailing industry, the sample consisted of both part time and full time workers.

Data used to proxy the retail price variable $(P)$ came from the Survey of Buying Power (published by Sales and Marketing Management Magazine), which provides aggregate annual sales data for each of the 9 retail categories above for each of our cities and years. ${ }^{11}$

\footnotetext{
${ }_{11}^{1}$ Made available since 1948, Survey of Buying Power (SBP) data are sold on a subscription basis to business owners, consultants, libraries, research organizations and various public agencies. Survey information is organized within a geographic hierarchy by region, state, metropolitan area, county and by television market. We used annual SBP data for 9 basic retail store groups for each of our specific metropolitan areas. These 9 groups generally match the groups used in the Current Population Survey. However, some of the groups are named differently for each survey. Specifically, what the CPS calls "grocery stores" is called "food stores" in the SBP, what the CPS calls "Department stores, variety stores and general merchandise stores" is simply called "General merchandise stores" in the SBP (although the SBP definition of stores in this category includes the three subcategories used by CPS), what CPS calls "Furniture and household furnishings stores" is called "Furniture, home furnishings and appliance stores" (the CPS category does include appliances) in the SBP, what CPS calls "Motor vehicle dealers" in the CPS is called "Automotive dealers" in SBP, and what CPS calls "Lumber and building material retailing and hardware stores" is called "Building materials and hardware dealers" in SBP. These particular data were lifted from the sections of the SBP data books titled "Retail Sales by Store Group for Metropolitan Markets and all Counties." They are interpolative estimates for each year based on the Census of Retail Trade. The estimates for 1979-82 are based on the 1977 Census and the estimates for 1983-85 are based on the 1982 Census.
} 
Dividends, interest and rents per capita for each city, obtained from the BEA website, ${ }^{12}$ are used to proxy the non-labor income variable $(\lambda)$ in our theoretical model. The FRED database is the source for U.S. GDP, U.S. CPI, and federal funds rate data. ${ }^{13}$ All monetary data are deflated using the CPI for the Southern region. ${ }^{14}$ City unemployment rates control for general labor market conditions and were obtained from the BLS, while birth and death rates were obtained from the Statistical Abstract of the United States.

We apply 3SLS to estimate Equations (15)-(17). The 3SLS method is not only efficient, but it is necessary for estimating the Wacziarg model because the joint estimation of the channel and aggregate equations produces a covariance matrix that we need to calculate the variances of the full channel effects, which are the products of corresponding coefficients from channel and aggregate equations. Since the Survey of Buying Power data on retail sales in each retail category are aggregate data, we chose to regress the weighted mean value of the dependent variable on the weighted mean values of the independent variables, where the weights are the fractions of Cuban, black, Hispanic or white workers. Consequently, the data set used in our regression analyses was compressed to 306 observations, where each observation is the mean value of a city-year-retail combination.

The estimation results for Equation (15) are presented in column two of Table 1. The dependent variable $\left(W_{N}\right)$ is the weighted average native retail wage for whites, blacks and Hispanics. Of the channel variables, the immigrant wage $\left(W_{I}\right)$ has a significant negative effect on retail wages, and retail sales per capita are significantly associated with higher native retail wages. Rent is a measure of "non-retail" goods and is positively associated with native retail wages, while the native retail wage appears not to be influenced by the minimum wage or technology.

Column three of Table 1 reports results when housing prices, measured by the Freddie Mac city specific repeated home sales index, are substituted for rents in Equation (15). The purpose of this substitution is two-fold. First, we are able to check the robustness of our results using different measures of city specific "non-retail" goods in the model, as mentioned by Saiz (2003). Saiz estimates that $92 \%$ of the Mariel immigrants were renters, not home owners, making rent an excellent consumption proxy for the Marielitos. However, rent data prior to 1982 had to be extrapolated with weighted averages. The coefficients in columns two and three of Table 1 are consistent, which suggests there is no obvious measurement error with the rent series.

Table 2 reports the results of the first channel Equation (16), which measures the input substitution effect. The dependent variable is the weighted average immigrant wage $\left(W_{T}\right)$. All else equal, it is positive and significantly related to the immigrant share and the amount of human capital obtained per worker. This result would seem to indicate the existence of a positive network effect among Cubans. That is, the greater the number of $\mathrm{Cu}$ ban immigrants as a share of the population, the greater the Cuban immigrant wage as newly arriving Cuban immigrants were able to obtain work in Miami. The immigrant wage is not affected by the other variables in the model, specifically, birth and death rates and emigration.

Table 3 reports the results of the second channel Equation (17), which measures the consumer demand effect. The dependent variable is retail sales per capita. Given that the

\footnotetext{
12 The data for dividends, interest and rent provided on the BEA website are aggregate data, but the same website also provides city population, so we computed the per capita numbers by combining the two measures.

${ }^{13}$ See http://research.stlouisfed.org/fred2/

${ }^{14}$ CPI data for Tampa are not available going back that far, so we chose to use the regional CPI for all 5 cities.
} 
Table 1. Estimated city retail wage equation (aggregate equation) dependent variable: weighted average native retail wage $\left(W_{N}\right)$

\begin{tabular}{lcc}
\hline & Equation (15) & Equation (15) \\
& Rent & House price \\
\hline Constant & 650.61 & 598.30 \\
& $(1.33)$ & $(1.18)$ \\
City minimum wage (Min) & -0.881 & -5.275 \\
& $(-0.01)$ & $(-0.04)$ \\
Immigrant Wage (W $\mathrm{I})$ & -0.372 & -0.392 \\
& $(-5.62)^{* *}$ & $(-5.13)^{\star *}$ \\
Retail sales per capita (P) & 0.239 & 0.281 \\
& $(4.75)^{* *}$ & $(5.85)^{* *}$ \\
U.S. Real GDP (RGDP) & -0.124 & -0.129 \\
& $(-1.79)^{*}$ & $(-1.49)$ \\
Technology (T) & 13.851 & 13.225 \\
& $(1.45)$ & $(1.13)$ \\
Rent & 0.106 & \\
& $(1.79)^{*}$ & 0.025 \\
House Price & & $(0.09)$ \\
R-Squared & 0.641 & 0.682 \\
\hline
\end{tabular}

Figures in parentheses are heteroskedasticity-consistent $t$-statistics.

** indicates significant at the $95 \%$ level, and * at the $90 \%$ level. There are 306 data points.

estimated coefficient $\left(c_{1}\right)$ is positive and significant, the results suggest that the inflow of Cuban immigrants generated a direct consumer demand effect on retail sales. Greater native wages are also significantly related to retail sales. Interest rates, national unemployment rates, real U.S. GDP growth, non-labor income, and the time trend do not significantly affect retail sales.

Table 2. Immigrant wage channel equation dependent variable: immigrant wage $\left(W_{I}\right)$

\begin{tabular}{lcc}
\hline & Rent & House price \\
\hline Constant & -46.322 & -64.128 \\
& $(-0.34)$ & $(-0.51)$ \\
Immigration $\left(\theta_{I}\right)$ & 8.146 & 7.897 \\
& $(3.29)^{* *}$ & $(3.04)^{* *}$ \\
Birth rate (Birth) & 1.313 & 2.176 \\
& $(0.28)$ & $(0.51)$ \\
Death rate (Death) & 2.929 & 3.422 \\
& $(0.40)$ & $(0.49)$ \\
Human capital (Human) & 16.702 & 17.335 \\
& $(3.11)^{* *}$ & $(3.08)^{\star *}$ \\
Emmigration (Emm) & -0.00001 & -0.00003 \\
& $(-0.04)$ & $(-0.12)$ \\
R-Squared & 0.790 & 0.801
\end{tabular}

Figures in parentheses are heteroskedasticity-consistent $t$-statistics.

** indicates significant at the $95 \%$ level, and * at the $90 \%$ level. There are 306 data points. 
Table 3. Retail sales channel equation dependent variable: retail sales per capita $(P)$

\begin{tabular}{lcc}
\hline & Rent & House price \\
\hline Constant & -1826.60 & -1877.10 \\
& $(-1.38)$ & $(-1.93)^{*}$ \\
Immigration $\left(\theta_{I}\right)$ & 23.238 & 22.006 \\
& $(5.88)^{* *}$ & $(6.22)^{* *}$ \\
Interest rates (interest) & 0.025 & -0.797 \\
& $(0.003)$ & $(-0.11)$ \\
National unemployment rate $(\mathrm{UN})$ & -11.468 & -16.035 \\
& $(-0.33)$ & $(-0.72)$ \\
Non-labor income $(\lambda)$ & -0.029 & -0.001 \\
& $(-0.75)$ & $(-0.05)$ \\
Native retail wage $\left(W_{N}\right)$ & 3.075 & 3.384 \\
& $(5.47)^{* *}$ & $(7.87)^{* *}$ \\
Real GDP growth $(G R G D P)$ & 0.361 & 0.344 \\
& $(1.12)$ & $(1.37)$ \\
Technology $(T)$ & -19.524 & -32.873 \\
R-Squared & $(-0.58)$ & $(-1.32)$ \\
\end{tabular}

Figures in parentheses are heteroskedasticity-consistent $t$-statistics.

** indicates significant at the 95\% level, and * at the 90\% level. There are 306 data points.

A summary of the channel effects of Cuban immigration on the wages of all natives, white natives only, black natives only, and Hispanic natives only are given in Table $4 .{ }^{15}$ The table reports the effects of each channel on a specific native wage category and, within a category, the effect of Cuban immigration on each channel. The last column reports the product of the two coefficients. Note that the $t$-statistics for the channel effects rely on a Taylor series expansion process. ${ }^{16}$ Results for all native workers (dependent variable $=$ weighted average native retail wage) confirm the theory in Section 2, as both the immigrant wage channel (input substitution effect) and the retail sales channel (consumer demand effect) have a statistically significant impact on the native wage. When both channels are added, the net effect of Cuban immigration on native wages is positive and at times significant. Overall, these results confirm that the consumer demand effect fully offsets the negative input substitution effect on wages, which then accounts for Card's (1990) finding that the Mariel influx overall had a benign effect on Miami area wages.

As Table 4 also shows, the results from splitting the sample into the three unique ethnic groups are reassuringly similar to the results for all natives. There is a significantly positive consumer demand effect present for whites, blacks, and Hispanics, suggesting that the new Cuban immigrants patronized shops and businesses of all ethnic back-

\footnotetext{
${ }^{15}$ We generated estimates for the three specific ethnic groups so as to stay consistent with Card's (1990) study. ${ }^{16}$ Wacziarg (1998) states that "The $t$-statistics for the channel effects are obtained by computing linear approximations of the products of the parameters around the estimated parameter values, and applying the usual formula for the variance of linear functions of random variables to this linear approximation. Computing these standard errors is possible thanks to the joint estimation of all the equations in the system, which allows the derivation of the covariance matrix for all of the estimated parameters." (pp. 23).
} 
Table 4. Summary of channel effects on native wages

\begin{tabular}{|c|c|c|c|c|}
\hline Dependent variable & Channel & $\begin{array}{l}\text { Effect of } \\
\text { channel on } \\
\text { native wage }\end{array}$ & $\begin{array}{l}\text { Effect of } \\
\text { immigration } \\
\text { on channel }\end{array}$ & $\begin{array}{l}\text { Effect of } \\
\text { immigration on } \\
\text { native wages }\end{array}$ \\
\hline \multicolumn{5}{|c|}{ Weighted average native retail wage (with rent) } \\
\hline & Immigrant wage & -0.372 & 8.146 & -3.030 \\
\hline & Channel $\left(\mathrm{W}_{\mathrm{T}}\right)$ & $(-5.62)^{* *}$ & $(3.29)^{* *}$ & $(-2.71)^{* *}$ \\
\hline & Retail sales per & 0.239 & 23.238 & 5.553 \\
\hline & capita channel $(P)$ & $(4.75)^{* *}$ & $(5.88)^{* *}$ & $(2.55)^{* *}$ \\
\hline & Total effect & & & 2.254 \\
\hline & $t$-statistic & & & $(2.16)^{* *}$ \\
\hline & Wald statistic & & & 4.658 \\
\hline & Wald $p$-value & & & $(0.03)$ \\
\hline & Sample size & & & 306 \\
\hline \multicolumn{5}{|c|}{ Weighted average native retail wage (with house price) } \\
\hline & Immigrant wage & -0.392 & 7.897 & -3.095 \\
\hline & Channel $\left(W_{T}\right)$ & $(-5.13)^{* *}$ & $(3.04)^{* *}$ & $(-2.36)^{* *}$ \\
\hline & Retail sales per & 0.281 & 22.006 & 6.183 \\
\hline & Capita channel $(P)$ & $(5.85)^{* *}$ & $(6.22)^{* *}$ & $(2.37)^{\star *}$ \\
\hline & Total effect & & & 3.088 \\
\hline & $t$-statistic & & & $(1.60)$ \\
\hline & Wald Statistic & & & 2.564 \\
\hline & Wald $p$-value & & & (0.109) \\
\hline & Sample size & & & 306 \\
\hline \multicolumn{5}{|c|}{ White native retail wage (with rent) } \\
\hline & Immigrant wage & -0.412 & 7.988 & -3.291 \\
\hline & Channel $\left(W_{T}\right)$ & $(-5.54)^{* *}$ & $(3.23)^{* *}$ & $(-2.65)^{* *}$ \\
\hline & Retail sales per & 0.261 & 23.709 & 6.108 \\
\hline & Capita channel $(\mathrm{P})$ & $(4.72)^{* *}$ & $(5.98)^{* *}$ & $(2.51)^{* *}$ \\
\hline & Total effect & & & 2.897 \\
\hline & $t$-statistic & & & $(2.12)^{* *}$ \\
\hline & Wald Statistic & & & 4.524 \\
\hline & Wald $p$-value & & & $(0.03)$ \\
\hline & Sample size & & & 306 \\
\hline \multicolumn{5}{|c|}{ Black Native Retail Wage (with rent) } \\
\hline & Immigrant wage & -0.403 & 7.628 & -3.074 \\
\hline & Channel $\left(\mathrm{W}_{\mathrm{I}}\right)$ & $(-3.05)^{* *}$ & $(3.03)^{* *}$ & $(-2.03)^{* *}$ \\
\hline & Retail sales per & 0.458 & 12.931 & 5.922 \\
\hline & Capita channel $(\mathrm{P})$ & $(5.53)^{* *}$ & $(3.20)^{* *}$ & $(2.52)^{* *}$ \\
\hline & Total effect & & & 2.848 \\
\hline & $t$-statistic & & & $(0.53)$ \\
\hline & Wald statistic & & & 0.284 \\
\hline & Wald $p$-value & & & $(0.59)$ \\
\hline & Sample size & & & 306 \\
\hline \multicolumn{5}{|c|}{ Hispanic native retail wage (with rent) } \\
\hline & Immigrant wage & -1.126 & 8.142 & -9.167 \\
\hline & Channel $\left(W_{T}\right)$ & $(-4.38)^{* *}$ & $(3.51)^{* *}$ & $(-2.34)^{* *}$ \\
\hline & Retail sales per & 1.082 & 16.809 & 18.187 \\
\hline & Capita channel $(\mathrm{P})$ & $(7.53)^{* *}$ & $(5.19)^{* *}$ & $(2.67)^{* *}$ \\
\hline & Total effect & & & 9.020 \\
\hline & $t$-statistic & & & $(0.19)$ \\
\hline & Wald statistic & & & 0.037 \\
\hline & Wald $p$-value & & & $(0.84)$ \\
\hline & Sample size & & & 306 \\
\hline
\end{tabular}

grounds. However, the evidence suggests a significantly negative immigrant wage channel for whites, blacks and Hispanics because Cubans served as substitute inputs for the three other ethnic groups. As with the weighted average results using rents and in line 
with previous authors' findings, native white wages were positively affected by a higher immigrant share. On the other hand, native black and Hispanic wages were on balance not affected by the Mariel influx. ${ }^{17}$

\section{Concluding remarks}

The theoretical model developed in this paper demonstrates that the net effect of immigration on native wages in a local economy is ambiguous because the arrival of immigrants both depresses wages through its effect on labor supply, but raises them through its effect on labor demand. Our estimates confirm that, for all native workers, the demand effect of immigration was substantial in Miami's retail labor market for at least the first half-decade following the Mariel Boatlift. In fact, we found that the consumer demand effect offsets the traditional labor substitution effect of immigration. When we estimate the Boatlift's effects separately for white, black, and Hispanic native workers, we find that the total effect of immigration on native black and Hispanic wages is positive and insignificant, but the effect of immigration on native white wages is positive and significant. We conclude, therefore, that Card's (1990) finding that the Mariel influx exerted no real effect on Miami-area wages is due to the new Cuban immigrants inducing a strong increase in the local demand for labor. Finally, the results of this study may be taken as further evidence supporting our contention that there is a "Say's Law of Immigration."

\section{References}

Altonji and Card, 1991 - Joseph Altonji and David Card, The effects of immigration on the labor market outcomes of less-skilled natives. In: John Abowd and Richard Freeman, Editors, Immigration, Trade and the Labor Market, University of Chicago Press, Chicago (1991).

Angrist and Kugler, 2003 - Joshua D. Angrist and Adriana Kugler, Protective or counter-productive? Labour market institutions and the effect of immigration on EU natives, Economic Journal 113 (2003), pp. F302-F331 (June).

Bodvarsson and Partridge, 2001 - Örn Bodvarsson and Mark D Partridge, A supply and demand model of customer, coworker and employer discrimination, Labour Economics 8 (3) (2001), pp. 389-416.

Bodvarsson and Van den Berg, 2006 - Örn Bodvarsson and Hendrik F. Van den Berg, Does immigration affect labor demand? Model and test. In: Solomon W. Polachek, Carmel Chiswick and Hillel Rapoport, Editors, Research in Labor Economics vol. 24, Elsevier, New York, NY (2006), pp. 135-166.

Borjas, 2003 - George J. Borjas, The labor demand curve is downward sloping: reexamining the impact of immigration on the labor market, Quarterly Journal of Economics 118 (4) (2003), pp. 1135-1174.

\footnotetext{
${ }^{17}$ We addressed two potential sources of reverse causality. First, we addressed potential endogeneity of the Cuban immigrant share $\left(\theta_{\mathrm{I}}\right.$ in Eqs. (16) and (17)) by instrumenting it with lagged immigrant shares (see, for example, Altonji and Card, 1991; LaLonde and Topel, 1991; Card, 2001). We are confident that the Cuban immigrant share for Miami is actually not endogenous because the Mariel influx was triggered by an exogenous policy shift outside the United States. Nevertheless, we instrumented $\theta_{1}$ with lagged foreign population share for each city in 1970 (we were not able to obtain a detailed breakdown of ethnic immigrant share at the city level for 1970, so we used the city's share of all foreign-born persons, obtained from the decennial 1970 census, instead). The IV results are reassuringly similar to the OLS, suggesting that simultaneity is not an issue in our study. Second, there is the possibility of two-way causality between wages and retail sales, since sales $=$ price $\times$ output and wages could influence price or output. Accordingly, we instrumented the retail sales per capita variable $(P)$ with real Gross State Product per capita (city GDP is not available for the time period under investigation). Those IV results are very similar to the OLS results, confirming as before a significantly positive consumer demand effect that outweighs a significantly negative input substitution effect. All the IV results are available from the authors upon request.
} 
Borjas, 2006 - George J. Borjas, Native internal migration and the labor market impact of immigration, Journal of Human Resources 56 (2) (2006), pp. 221-258.

Borjas et al., 1997 - George J. Borjas, Richard B. Freeman and Lawrence F. Katz, How much do immigration and trade affect labor market outcomes?, Brookings Papers on Economic Activity 0:1 (1997), pp. 1-67.

Card, 1990 - David Card, The impact of the Mariel Boatlift on the Miami labor market, Industrial and Labor Relations Review 43 (2) (1990), pp. 245-257.

Card, 2001 - David Card, Immigrant inflows, native outflows, and the local labor market impacts of higher immigration, Journal of Labor Economics 19 (1) (2001), pp. 22-64.

Card, 2005 - David Card, Is the new immigration really so bad, Economic Journal 115 (2005), pp. F300-F323 (November).

Carrington and de Lima, 1996 - William Carrington and Pedrode de Lima, The impact of 1970s repatriates from Africa on the Portugese labor market, Industrial and Labor Relations Review 49 (1) (1996), pp. 330-347.

Chiswick, 1978 - Barry Chiswick, The effect of Americanization on the earnings of foreign-born men, Journal of Political Economy 86 (1978), pp. 897-921 (October).

Cortes, 2006 - Cortes, Patricia, 2006. The Effect of Low-Skilled Immigration on U.S. Prices: Evidence From CPI Data, Unpublished Paper, University of Chicago Graduate School of Business.

Doll and Orazem, 1984 - John P. Doll and Frank Orazem, Production Economics: Theory and Applications, John Wiley and Sons, New York (1984).

Dustmann and Glitz, 2005 - Christian Dustmann and Albrecht Glitz, Immigration, jobs and wages: theory, evidence and opinion, CEPR-CReAM publication, London, UK (2005).

Federman et al., 2006 - Maya N. Federman, David E. Harrington and Kathy J. Krynski, Vietnamese manicurists: are immigrants displacing natives or finding new nails to polish?, Industrial and Labor Relations Review 59 (2006), pp. 302-318 (January).

Filer, 1992 - Randall K. Filer, The effect of immigrant arrivals on migratory patterns of native workers. In: George J. Borjas and Richard B. Freeman, Editors, Immigration and the Work Force: Economic Consequences for the United States and Source Areas, University of Chicago Press, Chicago (1992), pp. 245-269.

Freeman, 2006 - Richard B. Freeman, People flows in globalization, Journal of Economic Perspectives 20 (2006), pp. 145-170 (Spring).

Friedberg, 2001 - Rachel M. Friedberg, The impact of mass migration on the Israeli labor market, Quarterly Journal of Economics 116 (4) (2001), pp. 1373-1408.

Friedberg and Hunt, 1995 - Rachel M. Friedberg and Jennifer Hunt, The impact of immigrants on host country wages, employment and growth, Journal of Economic Perspectives 9 (2) (1995), pp. 23-44.

Frisch, 1965 - Ragnar Frisch, Theory of Production, Rand McNally, Chicago (1965).

Gandal et al., 2004 - Neil Gandal, Gordon H. Hanson and Matthew J. Slaughter, Technology, trade, and adjustment to immigration in Israel, European Economic Review 48 (2004), pp. 403-428.

Gaston and Nelson, 2001 - Noel Gaston and Douglas Nelson, The Employment and Wage Effects of Immigration: Trade and Labour Economics Perspectives, Research Paper no. 2001/28, Leverhulme Centre for Research on Globalisation and Economic Policy, University of Nottingham (2001).

Greenwood, 1994 - Michael J. Greenwood, Potential channels of immigrant influence on the economy of the receiving country, Papers in Regional Science 73 (3) (1994), pp. 211-240.

Greenwood and Hunt, 1984 - Michael J. Greenwood and Gary L. Hunt, Migration and interregional employment redistribution in the United States, American Economic Review 74 (1984), pp. 957-969.

Greenwood and Hunt, 1995 - Michael J. Greenwood and Gary L. Hunt, Economic effects of immigrants on native and foreign-born workers: complementarity, substitutability, and other channels of influence, Southern Economic Journal 61 (4) (1995), pp. 1076-1097.

Grieco and Ray, 2004 - Elizabeth Grieco and Brian Ray, Mexican Immigrants in the U.S. Labor Force, Migration Information Policy Institute, Washington, D.C. (2004); http://www.migrationinformation.org/USfocus/display.cfm?ID=206 
Grossman, 1982 - Jean B. Grossman, The substitutability of natives and immigrants in production, Review of Economics and Statistics 64 (1982), pp. 596-603 (November).

Harrison, 1983 - D.S. Harrison, The impact of recent immigration on the south Australian labor market, Report to Committee for the Economic Development of Australia, May (1983).

Hercowitz and Yashiv, 2002 - Zvi Hercowitz and E. Yashiv, A macroeconomic experiment in mass immigration. Institute for the Study of Labor (IZA) discussion paper \# 475; http://www.iza.org (2002).

Hunt, 1992 - Jennifer Hunt, The impact of the 1962 repatriates from Algeria on the French labor market, Industrial and Labor Relations Review 45 (3) (1992), pp. 556-572.

Kugler and Yuksel, 2006 - Kugler, Adriana and Yuksel, Mutlu, (2006), The Effects of Less-Skilled Immigrants on Natives: Evidence from Hurricane Mitch, Mimeo.

LaLonde and Topel, 1991 - Robert J. LaLonde and Robert H. Topel, Labor market adjustments to increased immigration. In: John M. Abowd and Richard B. Freeman, Editors, Immigration, Trade, and the Labor Market (1991).

Leamer and Levinsohn, 1995 - Edward E. Leamer and James A. Levinsohn, International trade theory: the evidence. In: Gene M. Grossman and Kenneth Rogoff, Editors, Handbook of International Economics vol. 3, Elsevier Science (North-Holland), Amsterdam (1995), pp. 1339-1394.

Lewis, 2003 - Ethan Lewis, Local open economies within the U.S.: how do industries respond to immigration?, Federal Reserve Bank of Philadelphia Working Paper No. 04-1 (2003).

Lewis, 2004 - Ethan Lewis, How did the Miami labor market absorb the Mariel immigrants?, Federal Reserve Bank of Philadelphia Working Paper No. 04-3 (2004).

Lewis, 2005 - Ethan Lewis, Immigration, skill mix, and the choice of technique, Federal Reserve Bank of Philadelphia Working Paper No. 05-8 (2005).

Longhi et al., 2005 - Simonetta Longhi, Peter Nijkamp and Jacques Poot, A meta-analytic assessment of the effect of immigration on wages, Journal of Economic Surveys 19 (3) (2005), pp. 451-477.

Mishan and Needleman, 1966 - E.J. Mishan and L. Needleman, Immigration, excess aggregate demand and the balance of payments, Economica 33 (1966), pp. 129-147 (May).

Mishan and Needleman, 1968 - E.J. Mishan and L. Needleman, Immigration: some long term economic consequences, Economica Internazionale 21 (1968), pp. 281-300 (May).

Ottaviano and Peri, 2005 - Gianmarco I.P. Ottaviano and Giovanni Peri, Rethinking the gains from immigration: theory and evidence from the U.S., National Bureau of Economic Research Working Paper 11672 (2005); http://www.nber.org/papers/w11672

Ottaviano and Peri, 2006 - Gianmarco I.P. Ottaviano and Giovanni Peri, Rethinking the effects of immigration on wages, National Bureau of Economic Research Working Paper 12497 (2006); http:// www.nber.org/papers/w12497

Poot et al., 1988 - J. Poot, G. Nana and B. Philpott, International Migration and the New Zealand Economy, Wellington Institute of Policy Studies (1988).

Saiz, 2003 - Albert Saiz, Room in the kitchen for the melting pot: immigration and rental prices, The Review of Economics and Statistics 85 (3) (2003), pp. 502-521.

Saiz, 2007 - Albert Saiz, Immigration and housing rents in American cities, Journal of Urban Economics 61 (2) (2007), pp. 345-371.

Suen, 2000 - Wing Suen, Estimating the effects of immigration in one city, Journal of Population Economics 13 (1) (2000), pp. 99-112.

Tavares and Wacziarg, 2001 - Jose Tavares and Romain Wacziarg, How democracy affects growth, European Economic Review 45 (8) (2001), pp. 1341-1378.

Wacziarg, 1998 - Romain Wacziarg, Measuring the dynamic gains from trade, Stanford University Working Paper, May, 1998 version (1998).

Wacziarg, 2001 - Romain Wacziarg, Measuring the dynamic gains from trade, World Bank Economic Review 15 (3) (2001), pp. 393-429. 